\title{
Administration and Technology in Industry
}

\begin{abstract}
TN a paper on "The Place and Function of the 1 Administrative and Technical Worker in the New Forms of Economic Structure" before Section F (Economic Science and Statistics) of the British Association on September 14, Mr. S. W. Smith directed attention to the growth and change of personnel which have accompanied the changes in the structure of industry and in industrial practice and technique in the last thirty-five years, particularly since the War. The mechanization and rationalization of industry have been accompanied by a significant growth in the importance of the technicians and scientific workers and the administrative staff, with a simultaneous reduction in the significance and proportion of unskilled labour and of controlling and directing owners of business. The bulk of the reorganization and modernizing work involved in the transformation of industry has been carried out by the technical and administrative staffs, and their importance has been further enhanced by the marked tendency for the proportion of professional, technical and administrative staffs to increase steadily in proportion to the remainder.
\end{abstract}

In support of his argument $\mathrm{Mr}$. Smith referred to figures from the 1930 Census of Production showing that the administrative staff in productive concerns increased by $12 \cdot 3$ per cent between 1924 and 1930 , excluding all those employed in shops, wholesale houses, banks, insurance companies, etc. Compared with 1907, while the total of operatives fell from $6,493,129$ to $6,417,514$, that of the administrative, clerical and technical staff rose from 490,947 to 723,920. Between 1911 and 1931, wages paid in industry receded from 42.5 to 41 per cent of the total, whereas in the same period salaries increased from 12 to 24 per cent. Between 1921 and 1931 professional workers increased by nearly 21 per cent, the increase in clerical staff being even more striking. Throughout the motor industry, the electrical and radio industries, and all branches of chemical industry the professional, scientific, technical and administrative staff played a dominant role, and it may be said that large business owes its existence chiefly to them. In turn, large business has provided them with the best and most abundant opportunity for their knowledge and skill. Virtually they constitute a new class, the most significant products of modern technique in industry and commerce, and in factory or office everywhere they occupy key positions.

The efficient functioning of large-scale business, whether manufacturing or distributive, largely depends upon these workers, who not only supply initiative and active control but also a constant flow of new ideas and inventions. Much the same holds with public utility corporations and municipal enterprises. Mr. Smith directed attention to the displacement or substitution of company proprietors or directors by responsible public officials, and the stipulation that a director should hold no shares whatever in order to secure that his dominant concern should be the public interest.

These changes have led to the question of training for industrial administration receiving growing attention. In the Post Office, a training school has been established in connexion with its Engineering Depart- ment where probationary assistant engineers receive a course of instruction in administration and finance. The conversion of potential proprietors into salaried managers and administrators also means that the speculative outlook of profit-seeking persons is replaced by the professional outlook with its prime interest in the efficiency of the work for its own sake. Since the salaried technician or administrator when reasonably and adequately paid tends to be interested in his work for its own sake, the functional outlook tends to replace the profit-seeking motive, care of the public interest and the spirit of service or trusteeship that of self-seeking or proprietorship.

This expansion of the administrative, technical and managerial sections of industry, with its increased stability of their income, has, however, been accompanied by a serious deterioration in the general security of all such salaried workers. The advent of unemployment among such workers who had previously been virtually immune has probably con. tributed to the widespread establishment among them of protective associations and trade unions, some fifty of which were represented at a Conference called a year or two ago by the National Federation of Professional Workers. Under present industrial tendencies, this increased precariousness and economic uncertainty of salaried workers is likely to continue, and its existence must be recognized in considering the significance of the place which administrative and technical workers now occupy both in industry and in society.

At a subsequent session on business administration, a number of these questions were again raised in Mr. C. A. Lee's paper on "Some Problems of a Small Manufacturing Business". The great asset of the small firm, Mr. Lee considers, is the way in which the closer contact possible with the head makes it possible for his personality to be felt right through the concern. This in itself is an important factor in developing a team spirit among the staff, which is just as important in a small as in a large firm for securing real co-operation, receptivity to new methods and keen interest in work. Moreover, the team spirit constitutes an effective check on slackness and grousing. Good leadership is most important and should endeavour to inspire the confidence that all concerned will be fairly treated, adequately paid and enjoy good working conditions. It is essential that the responsible staff should feel free to express ideas and have opportunity to advance. The problem of promotion may easily present real difficulty in a small firm. In regard to efficiency, while the small manufacturer cannot maintain the staff of experts employed by the larger firms, the use of outside consultants is a great help in introducing new ideas, and provided effective co-operation is secured with the staff, may be of real advantage in spite of the consultant's lack of knowledge of the particular business. In the discussion which followed, Mr. R. J. Mackay referred to the success which has attended the autonomous groups system described by $\mathbf{M}$. $\mathbf{H}$. Dubreuil before the Section in 1934 .

The paper by Mr. E. S. Byng which followed discussed the claims of administration to be considered a definite profession, involving a special technique 
and requiring a systematic scheme of education. Empirical methods of approach can no longer be considered adequate when our economic units are so large and their administration so complex, and it has become necessary to distinguish between the trained administrator who adopts a scientific approach to his problems, and the man who continues on rule-of-thumb methods. Administration may be defined as the co-ordination and control of all the specialized activities necessary to the effective operation of an industrial or other undertaking. Administration and specialist functions are closely interwoven in the senior positions of an industrial undertaking. While, for example, the managing director may be regarded as exercising 90 per cent administrative and 10 per cent technical functions, the works manager $66 \frac{2}{3}$ per cent administrative and $33 \frac{1}{3}$ per cent technical, the sales manager 60 per cent technical and only 40 per cent administrative, it is surprising how far down the seale some proportion of administrative function is involved.

The chief characteristics of modern industrial administration may be summarized as : functional division and devolution of responsibility, involving specialization and simplification; co-ordination of activities, involving the generation of the team spirit on a large scale ; and the substitution of fact analysis for guesswork, involving planning, costing and budgetary control. The impact of economic forces has driven industrialists to seek higher efficiency through the improved technique of specialists in all these departments. Their next problem is to bring about a parallel improvement in the technique of administration itself.
Mr. Byng referred to the way in which the responsibility of the administrator has been enhanced by specialized research into the conduct of industry, and stressed the importance of advances in industrial psychology and the study of human relationships. If the art of persuading men to work willingly and harmoniously is lacking, the real effectiveness of the undertaking is seriously impaired, and even complete failure may ensue. Sound laws of administration cannot be laid down without a clear understanding of human motives and desires embodying the char. acteristics of the group-mind, the effect of tradition, the response to varying incentives, the real causes of unrest and the emotional reactions to regulations and discipline. Accordingly, the responsibilities of the administrative function for the efficient development of industrial and commercial enterprise, for the effective use of capital and labour, and for the creation of means by which the increased wealth due to technological improvements in industry can be utilized for the greatest benefit of all concerned, carry social and economic consequences of national and indeed international importance.

Mr. Byng also discussed the question of education for administration both through such organizations as the Institute of Industrial Administration and within the ranks of industry itself. Finally, he urged that administration may justly claim to be a vital factor in industry and to offer an almost unlimited field of usefulness for the highest grades of intelligence. Our industrial future depends largely upon our methods of selecting and training administrators, and the general recognition of the high function they are called upon to perform.

\section{New Ultracentrifuge Installation at the Lister Institute}

$\mathrm{O}$ N Tuesday, September 29, the Governing Body and the Director of the Lister Institute entertained Prof. The Svedberg of Uppsala and a number of interested physicists, biochemists and biologists on the occasion of the completion of the new ultracentrifuge plant. In welcoming the guests, Prof. J. C. G. Ledingham explained that in anticipation of Prof. Svedberg's visit to London on his way home from the Harvard celebrations, every effort had been made to put the finishing touches to the new installation. Dr. McFarlane, Lister Institute fellow in biophysics and a former pupil of Prof. Svedberg, had been almost entirely responsible not only for the design of the building to accommodate the new plant, but also for the supervision of the lay-out and assembly of all the accessory connexions, electrical, optical, refrigerating, etc., carried out by the Institute's engineering staff. Throughout the whole work, he had enjoyed the constant advice amd co-operation of Prof. Svedberg. The total cost of the installation, including the new building, was about $£ 7,000$, of which sum the Rockefeller Foundation had most generously contributed $£ 3,400$ in defrayment of the cost of the new machines.

The new laboratory is specially designed and equipped for investigations into the physical nature of very small particles, particularly protein mole. cules, but it is hoped also to extend its use to the study of the less well-defined entities such as viruses phages and antibody complexes.

The ground floor is largely taken up by two ultracentrifuges and their auxiliary machinery. Both machines, which were made in the workshops of the University of Uppsala to the design of Prof. Svedberg, have optical arrangements which make it possible to observe and photograph the contents of the rotating cell.

The smaller of the two machines is called the equilibrium centrifuge and is used for the determination of absolute particle size or weight. It runs at speeds up to 18,000 r.p.m. and usually for several days and nights continuously. The particles have then ceased moving, and a state of sedimentation equilibrium is set up, which allows of the calculation of absolute size from the final photograph.

The larger machine generates much greater centrifugal forces, up to half a million times gravity, and serves to throw down even the smaller protein molecules completely in a few hours. It is used to measure the sedimentation velocity constant of pure proteins and of the components of a mixture. In the case of native protein mixtures, such as blood serum, it is possible to centrifuge these without previous chemical treatment and to determine from the photographs the concentrations in which the com. ponent proteins are present. 